\title{
The legacy of Design with Nature: from practice to education
}

\author{
William J. Cohen ${ }^{1}$ (D)
}

Received: 11 March 2019 / Accepted: 1 August 2019 / Published online: 30 August 2019

(c) Springer Nature Singapore Pte Ltd. 2019

\begin{abstract}
With the publication of Design with Nature - 50 years ago - what Ian McHarg did was open up a new door; he established a "new rule" to guide planning and designing our towns, cities, and regions that would embrace human ecology. Influenced by the intellectual guidance of his mentor, Lewis Mumford, McHarg can be credited with advancing ecohumanism in planning and design, both in practice and in education. The connection between human systems and natural systems lies at the foundation of ecohumanism and that becomes both a theory and a method to accomplish designing with nature. This alone would be the underlying thesis of Design with Nature. Just as important McHarg's dual roles as a practitioner of landscape architecture and regional planning and as an educator have, along with Design with Nature, secured a legacy that has stood the test of time—and remains so for the future.
\end{abstract}

Keywords Adaptation planning $\cdot$ Design with Nature $\cdot$ Ecohumanism $\cdot$ Ecological planning $\cdot$ Human ecological planning . Second Enlightenment · Ian L. McHarg

\section{Opening the door to a Second Enlightenment}

It was in the summer of 2006 when I encountered a kindred spirit urging that humankind must move from a technological culture to an ecological culture. At a round table discussion of fresh and fertile minds at the University of St. Andrews in Scotland, Graham Leicester, director of the International Futures Forum, quietly, yet firmly proclaimed, "Mere survival actually doesn't inspire any of us. It would be a start, but it's not enough. Our sense of future consciousness is that the thing that we want to and need to maintain and sustain is human aspiration" (2010, p. 169). To make this new direction perfectly clear and understood, Leicester drew on "the metaphor of the enlightenment" to make sense of our current complex reality. He explains that we are subject to "rapid technological change, new interconnectedness, speed of advance; we are in a world we don't understand anymore. The old rules no longer seem to apply. The new rules haven't been discovered. What we need is a Second Enlightenment" (2010, p. 171).

William J. Cohen

wjcohen@temple.edu

1 Temple University, Wilmington, USA
Fifty years ago a new human aspiration-indeed one of the "new rules" that Leicester spoke about-had its inauguration. It was the publication of Design with Nature by Ian L. McHarg (1920-2001) a landscape architect and regional planner at the University of Pennsylvania (Penn). The importance and value of Design with Nature is that it can be thought of as one of the essential guides to a Second Enlightenment. And as time would show, it would become the backbone of McHarg's entire career in both practice and education.

Ecohumanism is the foundation to Second Enlightenment thinking, and McHarg's unique legacy has demonstrated that we must engage planning, designing, and building cities and regions in a way that will maximize human potential and equally maximize environmental stewardship. The McHargian prescription is simply that there can be nothing less than an ecological imperative, melding both an understanding of natural systems and the complex array of human systems. In essence, this is how we can think of ecohumanism-a rejection of looking at the world only as a series of separate parts and embracing holism, emphasizing the interaction between many parts of the whole, thus focusing on systems and the interrelationships of their parts. Specifically, an ecohumanism approach provides an "insight into patterns of connectedness among individuals and between 
individuals and institutions and with the non-human environment" (Regal 2002, 62).

McHarg was a true ecohumanist having come under the influence of the personality and intellect of Lewis Mumford (1895-1990) one of the best known public intellectuals of the twentieth century. Mumford's voluminous writings engaged regional planning, architecture, American cultural history, art, technology, and his advancement of ecohumanism in city and regional planning education. Mumford and McHarg were faculty colleagues at Penn, and Mumford imparted to McHarg the indispensability of framing a system of designing with nature that would not just focus on natural systems, but equally engage human systems.

The power of Mumford's ecohumanism clearly had a lasting impact on McHarg as Mumford continually wrote and spoke about the natural physical world, the organic world, and human society. One assessment holds that Mumford "tried to formulate a comprehensive social theory for the twentieth century, weaving organismic philosophy, human ecology, and intellectual history into a unique and highly personal vision" (Jamison and Eyerman 1994, p. 87).

A clear manifestation of a new "social theory" began to take shape with the emergence of the American environmental movement of the 1960s. There were important and insightful writings that established an ethical base that would propel a new generation of environmental activists. Among them were Rachel Carson's Silent Spring (1962), Murray Bookchin's Our Synthetic Environment (1962), Barry Commoner's The Closing Circle: Nature, Man, and Technology (1971), and Aldo Leopold's A Sand County Almanac and Sketches Here and There (1949). Leopold's contribution was especially important in opening a new understanding of the human-environment relationship that would promote a new land ethic.

With McHarg's publication of his seminal work, Design with Nature in 1969, not only did it fuel the environmental movement but it added a key dimension in recognizing that there are limits to growth - that environmental issues need to be addressed as described by Carson, Bookchin, Commoner, Leopold, among others. The necessity of moving ecological planning, design, and building to the forefront would therefore become the challenge in designing with nature.

\section{Design with Nature: the opening salvo}

On the fiftieth anniversary of the publication of Design with Nature, it is fitting to recall that McHarg promoted what he called, ecological planning and ecological design. He developed both a theory and a method, the latter becoming a time tested approach to planning and designing human settlements.
While it is true that an "environmental conscience" was proffered by landscape architects and planners before McHarg, it took Design with Nature in 1969 and the celebration of the first Earth Day in 1970 to mobilize that consciousness to a new level in the practice of planning and design. Design with Nature would become the threshold occurrence that propelled McHarg into the national and international limelight.

Design with Nature begins with the proclamation, "The world is a glorious bounty," and ends with the prospect, "In the quest for survival, success and fulfillment, the ecological view offers an invaluable insight. It shows the way for man who would be the enzyme of the biosphere-its steward, enhancing the creative fit of man-environment, realizing man's design with nature" (McHarg 1969a, pp. 1, 197).

McHarg's "notion of planning" stems from "two fundamental characteristics of natural processes: creativity and fitness." Creativity, he holds, "provides the dynamics that govern the universe," while fitness derives "from Darwinian notions about how organisms adapt and survive" (McHarg 1978 , p. 140). When planning is linked to ecology, the goals and purposes become subject to the resources of the place, and "ecological planning" becomes an instrument for revealing the "interacting and dynamic natural systems having intrinsic opportunities and constraints for human use" (Ibid., p. 143).

Underscoring his philosophy — or ethical foundation-of planning and design is the essential premise that McHarg would continually describe as ecological determinism. Like many of McHarg's pronouncements, his characterization of ecological determinism was presented in a straightforward and self-evident manner. The framework of his staunch viewpoint was simply that the "understanding of natural process is of central importance to all environmental problems and must be introduced into all considerations of land utilization" (McHarg 1966, p. 54).

\section{Ecological and human ecological planning and design}

The indispensable technique that McHarg envisioned to fuse ecology to the planning and design process became known as the ecological planning method. To construct a practical method for planners and designers, McHarg developed a straightforward use of data and information that would become a two-step process. First, an assemblage of natural resource and physical features characteristics is portrayed as mapped layers in what would become known as the "layer cake."

Each layer represents a component of the natural and physical environment and includes, among others, the mapping of bedrock geology, surficial geology, 
groundwater hydrology, geomorphology, surficial hydrology, soils, vegetation, wildlife, land use, and climate. Each layer is then superimposed on each other to show the composite information and how each component of data relates to each other. McHarg was less concerned with each individual layer than with how they interact to form the natural landscape pattern. Figure 1 shows the original depiction of the layer cake model for ecological planning.

The second task in the method is to determine which areas in any given locale or on any given site are suitable for specific kinds of development. The locations containing the most propitious (i.e., suitable) factors for development would require less human adaptation to create habitat; therefore, development in these locations-based on natural resource constraints-would cause the fewest negative impacts on the environment. Therefore, this essential inventory of natural resource information and data allows the suitability of a subject land area to be determined.

Shortly after his death I wrote that McHarg "had a rare insight that enabled him to transform elementary principles of biological ecology into a humanistic prescription for a way to live and a way to plan. He held steadfastly to an approach to planning individual sites, cities, and entire regions that addressed human requirements without compromising the wondrous benefits of nature" (Cohen 2001, 13). This is at the crux of McHarg's transition from ecological to human ecological planning and design.

Human ecological planning emerges as the next iteration in McHarg's development of ecological planning. He expresses a concise view of this change that stems from a recognition of human ecology and how to incorporate it into human ecological planning and design. McHarg writes, "Ecology must be extended to include man. Human ecology
Fig. 1 The original layer cake representation of phenomena. Source: McHarg (1996a, 258)

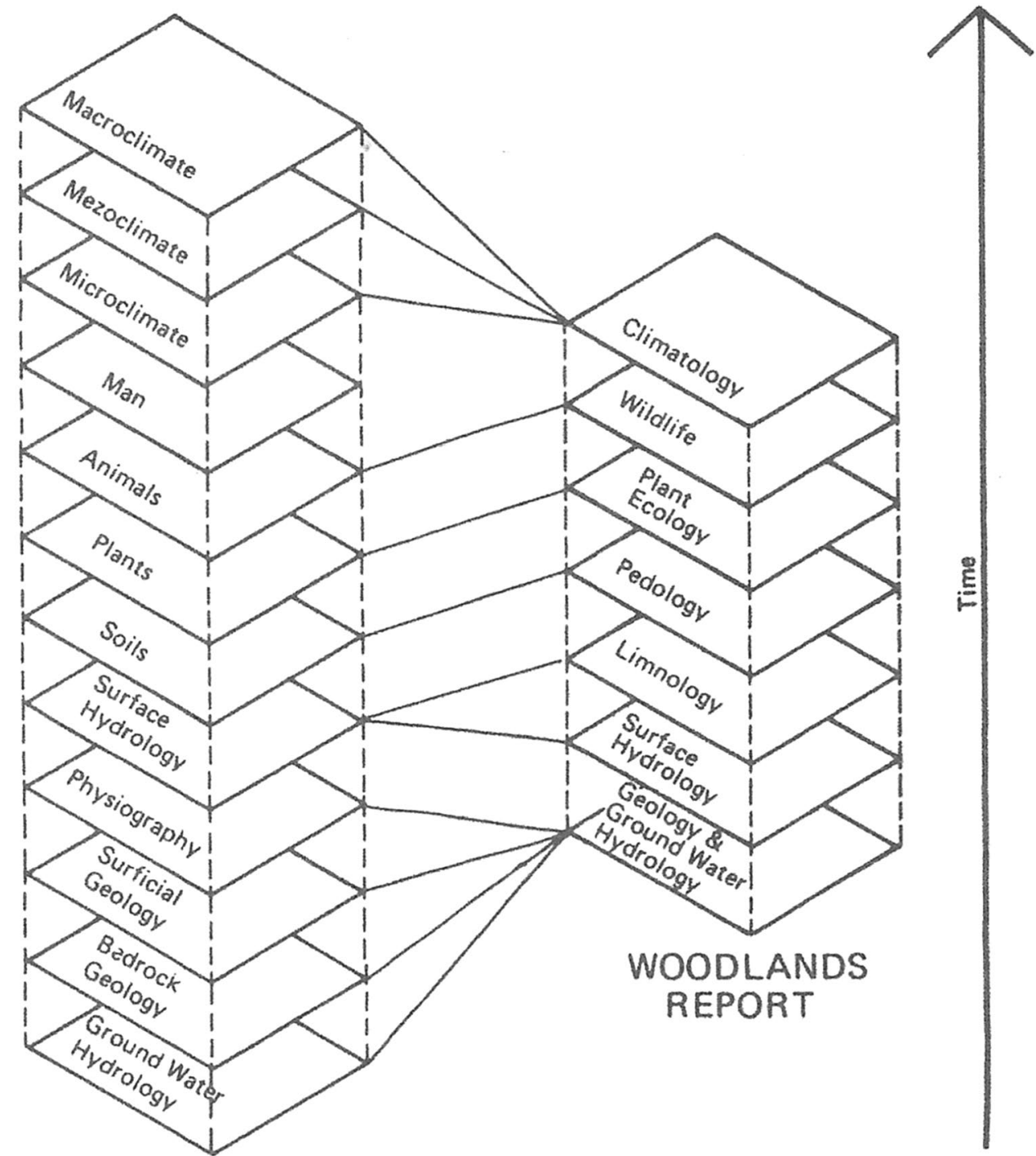

INVENTORY 
can then be defined as the study of the interactions of organisms (including man), and the environment (including man among other organisms)" (McHarg 1981, pp. 109-110).

McHarg makes an important distinction between ecological planning and ecological design. Since he held graduate degrees in city planning and landscape architecture, he understood that planning and design are distinctly different yet fill complementary roles, and he would blend the two disciplines as he constructed ecological and human ecological planning. Although the disciplines of landscape architecture and city and regional planning may overlap to some extent, they embody different approaches and methodologies in viewing two different parts of the whole; in McHarg's view, the whole becomes the total living and natural environment. In a 1997 essay, he clearly distinguishes between ecological planning and ecological design (McHarg 1997, p. 195).

Ecological planning is that approach whereby a region is understood as a biophysical and social process comprehensible through the operation of laws and time. This approach can be reinterpreted as having explicit opportunities and constraints for any particular human use. A survey will reveal the most fit locations and use.

Ecological design follows planning and introduces the subject of form. An intrinsically suitable location, processes with appropriate materials, and forms should exist. Design requires an informed designer with a visual imagination as well as graphic and creative skills. It selects for creative fitting revealed in intrinsic and expressive forms.

\section{McHarg's legacy in practice}

McHarg was truly a unique contributor to advancing landscape architecture and regional planning by first incorporating an ecological method and later a human ecological perspective in practice. He solidified this direction by promoting the design and implementation of a renowned interdisciplinary graduate curriculum at Penn that would guide the education of landscape architects and regional planners.

McHarg's impact on the practice of ecological planning and design has been acknowledged by former students, faculty colleagues, and others working in these professions. In the last published interview with McHarg, landscape architect Laurie Olin proclaims, "Ian's contribution to design and ecology has been enormous.... He got much of the world to view the earth through ecological glasses. A lot of current environmental legislation and methodology is a direct result of Ian's work" (Olin 2000, pp. 88-89). James Corner, another landscape architect, provides an important perspective: "Too many followers of McHarg simply adopted a methodology for practice, and while most shared his ecological ethics and viewpoint, they failed to grasp the larger conceptual, innovative, and artistic dimensions of what still lies in the potential of ecological concepts" (Corner 2007, pp. 98-99)

Over the years, he received many honors and accolades, which, if taken alone, would secure his legacy in the practice of landscape architecture and regional planning. For example, Lewis Hopkins, a former McHarg student and now professor emeritus of urban and regional planning at the University of Illinois, said "He introduced the biological metaphor for systems behavior into planning circles....Evolution of form, survival, adaptation, niche, interaction-he became the spokesperson for that way of talking about the world" (Thompson 1991, p. 14). Writing many decades after Design with Nature appeared the eminent landscape planner Carl Steinitz proclaimed that it was "probably the single most influential book in the field of landscape planning" (Steinitz 2009, p. 80).

Frederick Steiner has described the most important contribution of McHarg's work when he wrote that McHarg "opened a new way for us to see the world. His approach for interpreting the play between natural and cultural systems has become the dominant visualization technology of our time and provides a roadmap for applying ecological information to how we interpret, plan, and shape our surroundings" (Steiner 2017, p. 75). A key element in the "visualization technology" that Steiner refers to is in the evolution of geographic information systems (GIS) that "has enabled McHargian-style environmental analysis to become a commonplace methodological step in undertaking almost any form of local planning" (Beatley and Manning 1997, p. 86). The use of GIS therefore has become an indispensible tool to link databases (including environmental and social information) to maps.

An overview of the many consulting projects he was engaged in through his initial association with David Wallace from 1963 to 1964 and then with the firm Wallace, McHarg, Roberts and Todd (WMRT) from 1965 to 1980 offers a sense of the magnitude of his contribution to practice. Although McHarg was directly or indirectly involved in many projects, the following list includes those that I believe to be the most essential to advancing the practice of ecological and human ecological planning and design:

1964. Plan for the Valleys (Greenspring and Worthington Valleys, Baltimore County, Maryland): The first incorporation of ecology in a professional planning study (see McHarg 1965);

1965. Comprehensive Highway Route Selection Method (Princeton, New Jersey): The first use of environmental and social information to determine a highway route that would be the genesis of the environmental impact statement (see McHarg 1968); 
1967. Potomac River Basin The first use of the "layer cake" as the basis for the ecological inventory leading to the development of the ecological method (see McHarg 1969b);

1969. Twin Cities Region of Minnesota (Minneapolis-St. Paul) The first comprehensive regional ecological assessment and plan (see McHarg 1996b);

1973. Comprehensive Plan for Environmental Quality (with the American Institute of Planners) The first formal proposal for a national ecological inventory and the establishment of a national ecological laboratory as a precursor to the "Prototype Data Base for a National Ecological Inventory" using computer capability (see McHarg 1992); 1974. Woodlands New Community (Houston, Texas) The first determination of land use patterns and densities for a major development based on geohydrological properties (see McHarg 1979);

1974. Medford Township (New Jersey) The first use of ecologically based performance standards for new development (see McHarg 1974);

1975. Pardisan (Tehran, Iran) The first planned ecologically based international environmental park, promoting education, recreation, and conservation (see McHarg 1975).

\section{McHarg's legacy in education}

In 1965 a conference was convened by the Conservation Foundation to consider the future environments of North America. McHarg was one of over forty invited scholars and presented his paper, "Ecological Determinism." Lewis Mumford was also at that conference and was called on to give the closing remarks. Mumford addressed "The need for re-education of ourselves so as to get on top of a technological system that is destroying both organic variety and human choice." He pressed forward and argued for an educational curriculum "aimed not at producing more technicians, more engineers, more mathematicians, more scientists, but at producing more whole men and women, at home in every part of the environment" (Mumford 1967, 728).

It was during this time that McHarg was actively directing the establishment of a new graduate curriculum in regional planning and landscape architecture at Penn that would be based on ecology. As chairman of the Department of Landscape Architecture and Regional Planning, McHarg would grow a model interdisciplinary curriculum that would receive international acclaim and attract students from around the world.

The important thrust of the curriculum was twofold: first, under the guidance of then Dean G Holmes Perkins of the School of Fine Arts (today the Stuart Weitzman School of Design), the three disciplines of architecture, landscape architecture, and city and regional planning would become an intellectual partnership in furthering graduate education. Second, McHarg would pioneer an infusion of ecology in the pedagogical approach to regional planning and landscape architecture. This would later incorporate human ecology as the primary basis of course work and studios that the regional planners and landscape architects would be exposed to.

In telling the story of the pedagogical evolution, the events, and personalities surrounding the history of the Penn curriculum I wrote that McHarg would become "the key person to carry out Lewis Mumford's mission to initiate an educational component predicated on ecohumanism" (Cohen 2019, p. 105).

The incorporation of ecology into the regional planning and landscape architecture curricula at Penn alone is sufficient to secure McHarg's legacy in higher education. However, the one variable that gives McHarg's contribution a unique twist is that his influence and impact reached far beyond the academic walls of Penn. In fact many planners who spread the word and practiced either ecological planning or ecological design had been McHarg's students and, in a manner of speaking, thought of themselves as disciples. Robert Yaro (the president of the Regional Plan Association in New York) states unequivocally, "McHarg had a particularly profound impact on the nearly two generations of students he taught at the University of Pennsylvania. Many of them became leaders in the design professions as government officials, consultants, and teachers, and most have put Ian's environmental dogma and practices to work in their own careers" (Yarro 1998, x).

Another aspect of McHarg's accomplished role in education is the simple fact that his work at Penn influenced so many other academic institutions to adopt an ecological perspective in their educational curricula. The word was spread, principally through former Penn students and faculty colleagues in the Department of Landscape Architecture and Regional Planning but also by many others who were inspired by McHarg's emphasis on ecology as an indispensable intellectual and pragmatic foundation for the education of planners and designers. As these former students, colleagues, and followers of the McHargian approach began to assume teaching and administrative positions in colleges and universities, they confirmed and perpetuated his legacy in education.

At Penn McHarg's legacy has received special recognition. In the summer of 2017, the School of Design established the Ian L. McHarg Center for Urbanism and Ecology, an interdisciplinary research center focused on developing practical and innovative ways of improving the quality of life in places most vulnerable to the effects of climate change. The center was officially launched in conjunction with an international symposium held at Penn in 
June 2019 to honor the fiftieth anniversary of the publication of Design with Nature.

\section{Design with Nature: future prospects}

It is safe to say that the focus on ecology in evolving curricula in landscape architecture, landscape planning, city and regional planning, and environmental studies programs at many universities and colleges has at last become a reality that many educators have embraced.

The current emphasis in practice and in education to advance sustainability as a critical awareness and achievable goal as we plan, design, and build our places of habitation gives the infusion of ecology in such efforts additional legitimacy.

Both for today and tomorrow the legacy of Design with Nature presents a new challenge to planners and designers as we move to face the urban and regional growth and redevelopment possibilities of the twenty-first century. The reality is that we can no longer ignore the acute impacts on both our environment and our human habitat as a direct result of climate change and accelerated world-wide population growth. As Design with Nature offered a new hope and direction in the twentieth century, it has continued relevance and importance for us today. His lasting legacyand that of Mumford as well-is that he established the foundation that we can now build on.

So what does the future hold for Design with Nature? To begin, McHarg argued for the initiation of "massive global ecological inventories... [that] would be seen as the primary consequence of recognizing the global environment as the principal objective in the world's agenda" (McHarg 1996a, 374).

Such a charge leads directly to confronting the challenges facing all of us revolving around the imminent affects of climate change. We are beyond the days of just planning and designing for community and regional sustainability, which, of course, must continue. What is now needed is to project the mantra of Design with Nature to address adaptation planning. This would embrace several approaches:

- Protection planning aimed at protecting communities that are location-dependent such as downtown centers and historic areas;

- Accommodation planning strategies that alter the design of new development to reduce the potential damaging risks of natural events;

- Managed retreat planning the actual removal of existing development and possible relocation to other areas, as well as the public acquisition of vulnerable land;
- Avoidance planning To ensure that development does not take place in locations that are prone to negatively impacting environmental resources.

A fitting assessment for the future was proclaimed by McHarg when he stressed that we must "learn the way the world works" which in turn will usher in the ecological era as "the most important challenge to education and society" (McHarg 1996a, 370).

\section{Conclusions}

Our path forward needs to recognize that in planning, designing, and building cities and regions, the traditional guideposts of order, form, sense of place, and beauty should not be replaced by computer techniques and tools that could, if overemphasized, become surrogates to human imagination and creativity. So the essence of the challenge to city and regional planners and landscape architects will be to strike out in new yet compatible directions. One such directionor new synthesis-offers substantial promise to ensure that the fundamental precepts of ecology will remain the soul of planning and designing.

Beginning with a fusion of ecological planning and landscape ecology, present trends are firming up the connections between planning and design. Whatever this new direction is called-landscape ecology, urban ecology, or landscape ecological urbanism-it is a current move to genuinely transform the education and professional practice of planners and landscape architects that will encompass an ecohumanism understanding of people, places, and environment. The direction forward is not to rely on maintaining strict and separate disciplinary roles but to fully incorporate that interdisciplinary amalgam that will guide the next generation. This, then, will serve as the justification to develop a curriculum based on ecohumanism as a new and forward vision for the education of planners and designers.

In the final analysis the legacy of Design with Nature will maintain its indispensability as the challenge and the guide post to embrace and advance ecohumanism. Design with Nature will stand the test of time, not because McHarg acknowledged it to be his "single most powerful identification" (1996a, 206), but as Mumford believed, "it will have a long and fruitful life" (Mumford 1969).

\section{References}

Beatley T, Manning K (1997) The ecology of place: planning for environment, economy, and community. Island Press, Washington Cohen WJ (2001) Ian McHarg's triumph. Planning 67(5):10-13 
Cohen WJ (2019) Ecohumanism and the ecological culture: the educational legacy of Lewis Mumford and Ian McHarg. Temple University Press, Philadelphia

Corner J (2007) The McHarg event: an unfinished project. In: Margulis L, Corner J, Hawthorne B (eds) (2007) Ian McHarg conversations with students: dwelling in nature. Princeton Architectural Press, New York, 97-99

Jamison A, Eyerman R (1994) Seeds of the sixties. University of California Press, Berkeley

Leicester G (2010) The St. Andrews conversation. In Cousineau P, Zelov C (eds) (2010) City21: the search for the second enlightenment. The Knossus Project, Hellertown, 169-186

McHarg IL (1965) Plan for the valleys vs. spectre of uncontrolled growth. In McHarg IL, Steiner FR (eds) (1998) To heal the earth: selected writings of Ian L. McHarg. Island Press, Washington, 271-277

McHarg IL (1966) Ecological determinism. In: McHarg IL, Steiner FR (eds) (1998) To heal the earth: selected writings of Ian L. McHarg. Island Press, Washington, 39-56

McHarg IL (1968) A comprehensive highway route selection method. In: McHarg IL, Steiner FR (eds) (1998) To heal the earth: selected writings of Ian L. McHarg. Island Press, Washington, 219-233

McHarg IL (1969a) Design with nature. Natural History Press, Garden City

McHarg IL (1969b) The river basin. In McHarg IL (1969) Design with nature. Natural History Press, Garden City, 127-151

McHarg IL (1974) Medford. In McHarg IL (1996) A quest for life: an autobiography. Wiley, New York, 273-285

McHarg IL (1975) Pardisan 1973-1975. In: McHarg IL (1996) A quest for life: an autobiography. Wiley, New York, 290-296

McHarg, IL (1978) Ecological planning: the planner as catalyst. In McHarg IL, Steiner FR (eds) (1998) To heal the earth: selected writings of Ian L. McHarg. Island Press, Washington, 139-141

McHarg IL (1979) A case study in ecological planning: the woodlands, Texas. In McHarg IL, Steiner FR (eds) (1998) To heal the earth: selected writings of Ian L. McHarg. Island Press, Washington, 243-263

McHarg IL (1981) Human ecological planning at Pennsylvania. Landsc Plan 8:109-120

McHarg IL (1992) A strategy for a national ecological inventory. In: McHarg IL, Steiner FR (eds) (1998) To heal the earth: selected writings of Ian L. McHarg. Island Press, Washington, 341-356
McHarg IL (1996a) A quest for life: an autobiography. Wiley, New York

McHarg IL (1996b) The ecological study for the twin-cities metropolitan area. In: McHarg IL (1996) A quest for life: an autobiography. Wiley, New York, 253-255

McHarg IL (1997) Ecology and design. In McHarg IL, Steiner FR (eds) (1998) To heal the earth: selected writings of Ian L. McHarg. Island Press, Washington, 341-356

Mumford L (1967) Closing statement. In: Darling FF, Milton JP (eds) Future environments of north America. Natural History Press, Garden City, pp 718-729

Mumford L (1969) Letter to Ian McHarg, May 27, 1969. 109.II.B.1.14 McHarg collection, the Architectural Archives University of Pennsylvania

Olin L (2000) Quoted in Ken Shulman, the gospel according to Ian McHarg. Metropolis 20(1):86-89, 103, 105

Regal PJ (2002) Ecohumanism: refining the concept. In: Tapp RB (ed) (2002) Ecohumanism. Prometheus Books, Amherst

Steiner FR (2017) Healing the earth: the relevance of Ian McHarg's work for the future. Human Ecol Rev 23(2):75-85

Steinitz C (2009) Landscape planning: a history of influential ideas. Landsc Archit 99(2):74-83

Thompson W (1991) A natural legacy: Ian McHarg and his followers. Planning 57(11):14-19

Yarro RD (1998) Foreword. In McHarg IL, Steiner FR (eds) (1998) To heal the earth: selected writings of Ian L. McHarg. Island Press, Washington, ix-xi

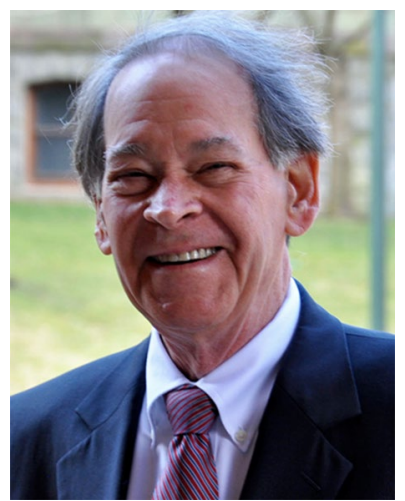

William J. Cohen is a Fellow of the American Institute of Certified Planners and an Associate Professor of Practice in the Department of Architecture and Environmental Design at Temple University's Tyler School of Art and Architecture. He holds the Ph.D. in City and Regional Planning from the University of Pennsylvania. 